\title{
AN APPROACH OF FLOW MEASUREMENT IN SOLAR WATER HEATER USING TURBINE FLOW METER
}

\author{
N.R.Kolhare \\ Professor GEC Aurangabad
}

\author{
P.R.Thorat \\ Assistant Professor SPWEC
}

\begin{abstract}
The cost effectiveness in solar system is very essential to boost its use in domestic applications. A Techno-economical system is designed using microcontroller based turbine flow meter to measure flow of water in solar water heater. There is no need of bulky remote electronics system. Here a turbine is inserted in the pipeline which rotates around its axis the speed of this rotation is directly proportional to the rate of flown.

To measure the flow electronically through noncontact method one arm of the turbine can be made of a magnet and a Hall Effect device attached on the outer side of the pipe. The Hall Effect switch would pick up the passage of the magnetic arm and generates a pulse. By counting the number of pulses per second or minute depending on the speed of the turbine and the desired resolution (i.e. multiplication factor) the flow can be calculated.
\end{abstract}

\section{INTRODUCTION}

Energy is the lifeblood of our society. Solar can be effectively utilized in two ways-either by converting it into heat (Solar thermal) or electricity (Solar photovoltaic cell). With great concerns being voice about the decreasing fossil fuel reserves and increasing environmental pollution resulting from the burning of large quantities of fossil fuel, the use of renewable sources of energy that are never ending and relatively cleaner has gained a lot of importance. Since the eighties a lot of thought has gone into how we can extend the life of our fossil fuel reserves and as a consequence cut down on pollution. A lot of work has been done on using renewable sources of energy like solar, wind, tidal etc.

Basic Solar Water Heating System

A Solar water system consists of following major components:

- Solar Collector(s)

- Insulated Hot water Tank with Sacrificial Anode

- $\quad$ Indicating and Control Instruments

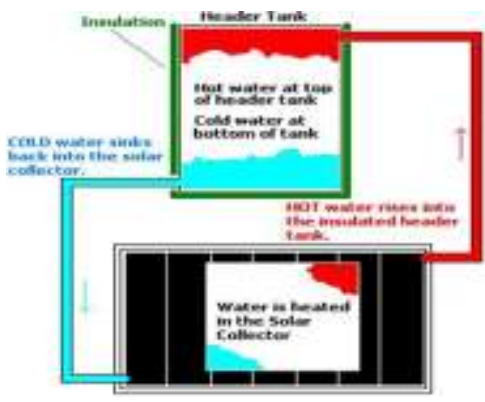

Figure1: Basic Solar Water Heating System

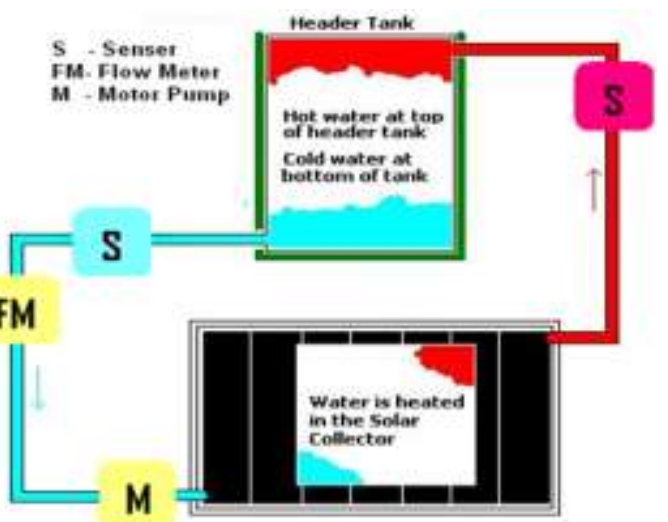

Figure2: Controlled Solar Water Heating System

In controlled solar water heater system with the help of feedback from flow meter helps to control mixture temperature in main tank. Hence role of flow meter is most important in such systems. Here cost aspect is most important to make system low cost, as only flow meter is very costly compare to sensor and motor part

\section{Selection of Flow Meter}

With most liquid flow measurements instrument, the flow rate is determined inferentially by measuring the liquids, velocity or the change in kinetic energy. Velocity depends on the pressure differential that is forcing the liquid through price or conduit. Because the pipe's cross-sectional area is known and remains constant, the average velocity is an indication of the flow rate. The basis relationship for determining the liquid's flow rate in such cases is:

$\mathrm{Q}=\mathrm{V} \times \mathrm{A}$

Where, $\mathrm{Q}=$ Liquid flow through the pipe

$\mathrm{V}=$ Average velocity of the flow

$\mathrm{A}=$ Cross-sectional area of the pipe

Other factors that affect liquid flow rate include the liquid's viscosity and density, and the friction of the liquid in contact with the pipe.

Direct measurements of liquid flows can be made with positive- displacement flow meters. These units divide the liquid into specific increments and move it on. The total flow is an accumulation of the measured increments, which can be counted by mechanical or electronic techniques

\begin{tabular}{|l|l|}
\hline Principle & Types \\
\hline Differential Pressure & $\begin{array}{l}\text { Orifice Plate, Venturi Tube, Flow } \\
\text { Tube, Flow Nozzle, Pitot Tube, } \\
\text { Elbow Tap, Variable-Area (Rota } \\
\text { Meter) }\end{array}$ \\
\hline Positive Displacement & $\begin{array}{l}\text { Reciprocating Piston, Oval Gear, } \\
\text { Nutating Disc, Rotary Vane }\end{array}$ \\
\hline
\end{tabular}




\begin{tabular}{|l|l|}
\hline Velocity & $\begin{array}{l}\text { Turbine, Vortex } \\
\text { Electromagnetic, } \\
\text { Doppler, Ultrasonic Transit Time }\end{array}$ \\
\hline Mass & Coriolis, Thermal \\
\hline Open-Channel & Weir, Flume \\
\hline
\end{tabular}

Table1: Flow Meter Types

\section{Turbine Flow Meter}

The turbine flow meter translates the mechanical action of the turbine rotating in the liquid flow around an axis into a userreadable rate of flow (gpm, lpm, etc.).The turbine wheel is set in the path of a fluid stream. The flowing fluid impinges on the turbine blades, imparting a force to the blade surface and setting the rotor in motion. When a steady rotation speed has been reached, the speed is proportional to fluid velocity. There is much different manufacturing design of turbine flow meters, but in general they are all based

on the same simple principle: If a fluid moves through a pipe and acts on the vanes of a turbine, the turbine will start to spin and rotate. The rate of spin is measured to calculate the flow.

The turndown ratios may be more than 100:1 if the turbine meter is calibrated for a single fluid and used at constant conditions. Accuracy may be better than $+/-0.1 \%$

\section{Industrial Flowmeter Usage}

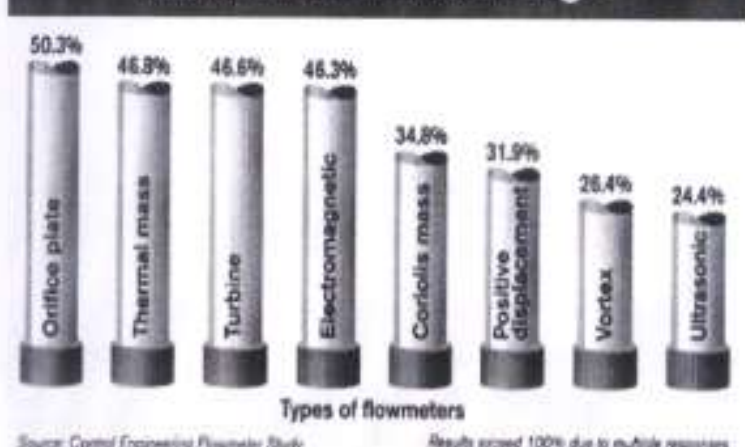

Figure3: Industrial Flow Meter Usage

\section{SYSTEM DEVELOPMENT}

For measuring flow rate of liquid standard sensors can be used which are in flow rate measuring field but cost of these sensors is very high so it is desired to use sensors which are having low cost, in the developed system use the sensors which gives the standard value. For measuring flow rate A1201 or A1202 sensor is used.

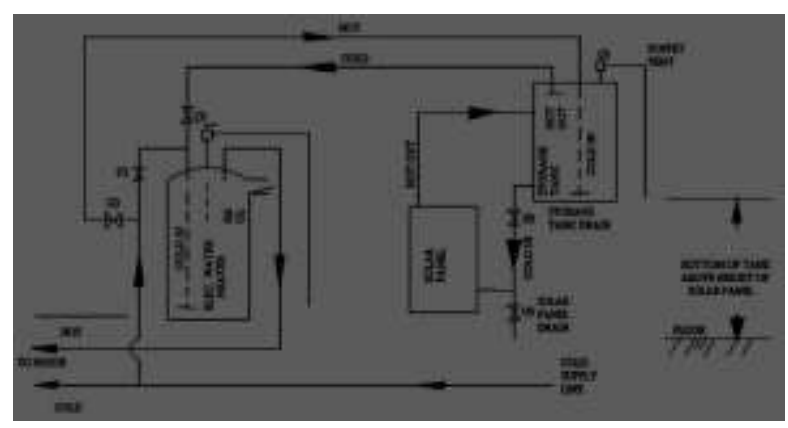

Figure 4: System Block Diagram

Fluid entering the meter passes through the inlet flow straightened which reduces its turbulent flow pattern and improves the fluid's velocity profile. Fluid then passes through the turbine blades causing it to rotate at a speed proportional to the fluid velocity. As each blade passes through the magnetic field, created at the base of the pickoff transducer, AC voltage (pulse) is generated in the pick-up coil (see Figure). These impulses produce an output frequency proportional to the volumetric flow through the meter. The output frequency is used to represent flow rate and/or tantalization of fluid passing through the turbine flow meter.
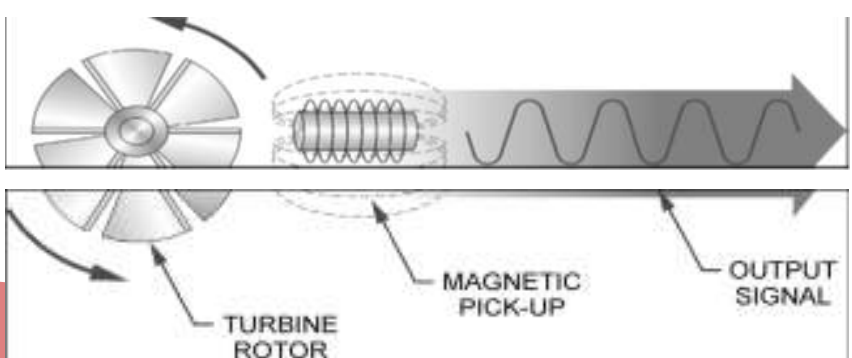

Figure 5: Schematic Illustration of Electric Signal Generated by Rotor Movement

The Turbine Flow Meter is designed to withstand the rigorous demands of the most remote flow measurement applications. Flow Meter maintains measurement accuracy and mechanical integrity in the corrosive and abrasive fluids commonly found in oil field water flood project pipelines, in-situ mining operations, offshore facilities and plant locations. Simple to install and service, it can operate in any orientation (horizontal to vertical) as long as the "flow direction" arrow is aligned in the same direction as the actual line flow. For optimum performance, the flow meter should be installed with a minimum of 10 diameters upstream pipe length and 5 diameters downstream pipe length [19].

\section{PERFORMANCE ANALYSIS}

Calibration and its Observation

\begin{tabular}{|l|l|l|l|}
\hline $\begin{array}{l}\text { Sr. } \\
\text { No. }\end{array}$ & $\begin{array}{l}\text { Multiplication } \\
\text { Factor }\end{array}$ & $\begin{array}{l}\text { Observed } \\
\text { Reading } \\
\text { (LPM) }\end{array}$ & $\begin{array}{l}\text { Actual } \\
\text { Reading } \\
\text { (LPM) }\end{array}$ \\
\hline 1 & 1.5 & 22 & 25 \\
\hline 2 & 1.6 & 23.5 & 25 \\
\hline 3 & 1.7 & 24 & 25 \\
\hline 4 & 1.8 & 25 & 25 \\
\hline 5 & 1.9 & 26.3 & 25 \\
\hline 6 & 2.0 & 28 & 25 \\
\hline 7 & 2.1 & 29.5 & 25 \\
\hline
\end{tabular}

Table 2: Calibration and its Observation

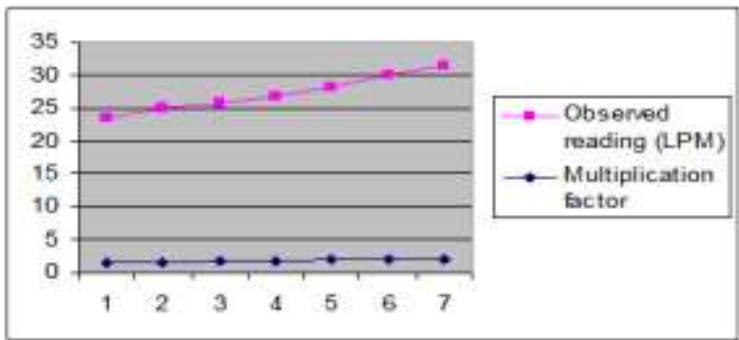

Graph 1: Calibration Process 
Comparison between Standard and Experimental Analysis

\begin{tabular}{|r|l|l|l|l|l|}
\hline $\begin{array}{l}\text { Sr. } \\
\text { No. }\end{array}$ & $\begin{array}{l}\text { Std. } \\
\text { Volume } \\
\text { Liter }\end{array}$ & $\begin{array}{l}\text { Std. } \\
\text { Time } \\
\text { Sec. }\end{array}$ & $\begin{array}{l}\text { Std. } \\
\text { Flow } \\
\text { Rate } \\
\text { LPM }\end{array}$ & $\begin{array}{l}\text { System } \\
\text { Flow } \\
\text { rate } \\
\text { (LPM) }\end{array}$ & $\begin{array}{l}\text { Error } \\
(\text { LPM) }\end{array}$ \\
\hline 1. & 0.00 & 60 & 0.00 & 0.00 & 0.00 \\
\hline 2. & 5.52 & 60 & 5.52 & 5.40 & 0.12 \\
\hline 3. & 10.18 & 60 & 10.18 & 10.00 & 0.18 \\
\hline 4. & 15.28 & 60 & 15.28 & 15.00 & 0.28 \\
\hline 5. & 31.32 & 60 & 31.32 & 31.00 & 0.32 \\
\hline 6. & 41.40 & 60 & 41.40 & 41.00 & 0.40 \\
\hline
\end{tabular}

Table 3: Comparison between Standard and Experimental Analysis

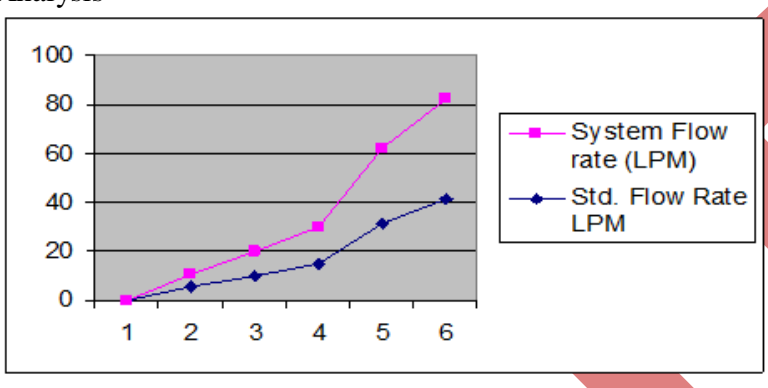

Graph 2: Comparison Standard and Experimental Analysis

\section{CONCLUSION}

Development of Solar Water Heater Flow measurement using micro controller based Turbine Flow Meter will replace the other conventional system used in Solar Water Heater flow measurement This system eliminates the manual mistakes in flow rate measurements. It increases the accuracy in flow rate measurement.

This system is more attractive, as it provides automatic operation; hands free, long-range identification supports, as well as cover monitoring applications. Also can be used for different viscosity liquids only by changing multiplication factor Sensors designed in the developed system are very cost effective and accurate.

Please use a 9-point Times Roman font, or other Roman font with serifs, as close as possible in appearance to Times Roman in which these guidelines have been set. The goal is to have a 9-point text, as you see here. Please use sans-serif or non-proportional fonts only for special purposes, such as distinguishing source code text. If Times Roman is not available, try the font named Computer Modern Roman. On a Macintosh, use the font named Times. Right margins should be justified, not ragged.

\subsection{Title and Authors}

1) Prof. N. R. Kolhare is working as a assistant professor in government engineering college Aurangabad.

2) Prof. P. R. Thorat is a research scholar and working as a assistant professor at Savitribai Phule Women's Engineering College Aurangabad. 6. ACKNOWLEDGMENTS

I feel great pleasure in submitting this Dissertation "Solar Water Heater Flow Measurement Using Microcontroller
Based Turbine Flow-Meter". I wish to express true sense of gratitude towards my Dissertation guide, N. R. Kolhare who at very discrete step in study of this subject, contributed her valuable guidance and help to solve every problem that arose.

I would wish to thank our HOD Dr. A. S. Bhalchandra for opening the doors of the department towards the realization of the Seminar report.

I would like to extend my special thanks to Principal Dr. P. S. Adwani for spending his valuable time to go through my report and providing many helpful suggestions.

Most likely I would like to express my sincere gratitude towards my family and friends; with all respect and gratitude, I would like to thank all the people, who have helped me directly or indirectly. I owe my all success to them.

\section{REFERENCES}

[1] W. F. Z. Lee, and H. J. Evans, and Reynolds number Density effect on gas turbine flow meters, Trans. ASME, J. Basic Eng., 87 (4): 1043-1057, 1965.

[2] R. E. Thompson, and J. Grey, Turbine flow meter performance model, Trans. ASME, J. Basic Eng., $92(4): 712-723,1970$.

[3] M. B. Pate, A. Myklebust, and J. H. Cole, A computer simulation of the turbine flow meter rotor as a drag body, Proc. Int. Compute. In Eng. Conf. and Exhibit 1984, Las Vegas: 184-191, NY, NY: ASME, 1984.

[4] P. D. Olivier, and D. Ruffner, Improved turbine meter accuracy by utilization of dimensionless data, Proc. 1992 Nat. Conf. Standards Labs. (NCSL) Workshop and Symp. 595-607, 1992.

[5] ISA-RP 31.1, Specification, installation and calibration of turbine flow meters, Research Triangle Park, NC: ISA, 1977.

[6] ANSI/ASME MFC-4M-1986 (R1990), Measurement of gas flow by turbine meters, NY, NY:ASME.

[7] API MPM, Ch. 5.3, Measurement of liquid hydrocarbons by turbine meters, $3^{\text {rd }}$ Ed., Washington, DC: API (Amer. Petroleum Inst.), 1995.

[8] AGA Transmission Meas. Committee Rep. No. 7, Measurement of fuel gas by turbine meters, Arlington, VA: AGA (Amer. Gas Assoc.), 1981.

[9] Int. Recommendation R32, Rotary piston gas meters and turbine gas meters, Paris, Fr.: OIML (Int. Organization of Legal Metrology), 1989.

[10] ISO 9951:1993, Measurement of gas flow in closed conduits - turbine meters, Geneva, Switz.: Int. Organization for Standardization, (also available ANSI), 1993.

[11] T. H. J. J. Van Der Hagen, Proof of principle of a nuclear turbine flow meter, Nucl. Technol., 102 (2): 167-176, 1993.

[12] K. Termaat, W. J. Oosterkamp, and W. Nissen, Nuclear turbine coolant flow meter, U.S. Patent $5,425,064,1995$. 
Council for Innovative Research www.cirworld.com

[13] AWWA C704-92, Propeller-type meters for waterworks applications, Denver, CO: Amer. Water Works Assoc., 1992.

[14] ANSI/AWWA C701-88, Cold water meters turbine type, for customer service, Denver, CO: Amer. Water Works Assoc., 1988.

[15] B. M. Wright, and C. B. McCarron, Maximum forced expiratory flow rate as a measure of ventilatory capacity, Brit. Med. J.: 1041-1047, 1959.

[16] Hemi Sagi \& William G. Roberts- Inline flow meters calibration advance methods \& solutions. ( NCSL) 1997 www.atcinc.net
International Journal of Computers \& Technology Volume 4 No. 1, Jan - Feb, 2013

[17] Li-gang, Li-qiao-Zen, Zang hai-Peng- Study of the application of the turbine flow meters. (IEEE) V3 445-447.

[18] M. Vishwanathan Microprocessor based flow rate \& flow volume indicator common for any flow sensor which gives pulse output 1998 (IEEE) 1083-1087

[19] Gang-Li Qiao-Zhen Feng Dong- Study on wide range turbine flowmeter-2006 (IEEE) 775-778.

[20] "Solar Energy" (Principal of Thermal Collection and Storage), by S. P. Sukhatme, J.K.Nayak. , 3639 .

[21] "Solar Energy Utilization", by G. D. Rai., 312-319.

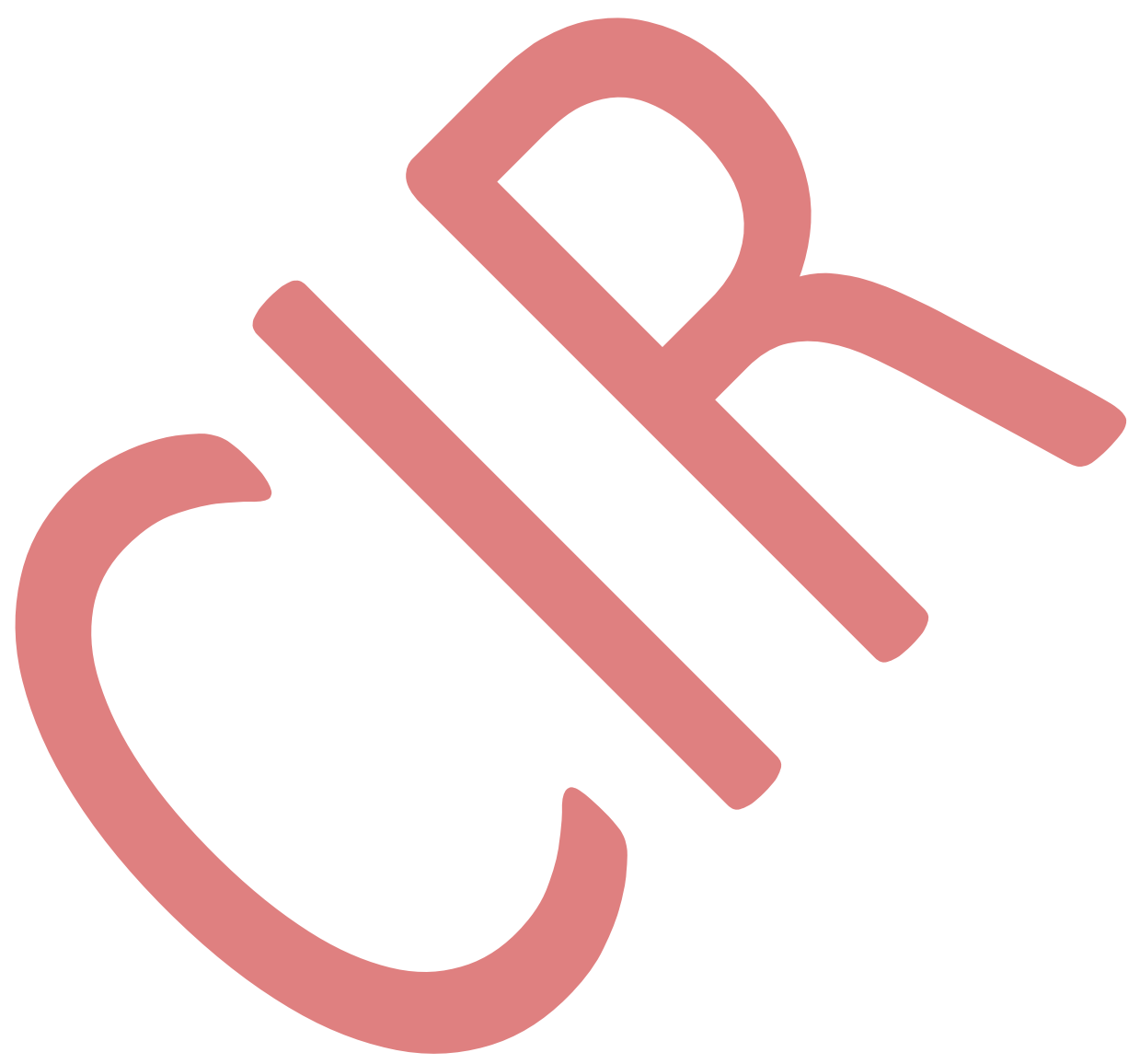

